\title{
Perceived learning outcomes from participation in one type of registered student organization: Equestrian sport clubs
}

\begin{abstract}
Erin Mikulec $^{1}$ and Kathleen McKinney ${ }^{2}$
Abstract: Learning takes place both inside and outside of the classroom. While there are a few studies that focus on the professional, developmental, and learning outcomes of participation in student organizations, there has been insufficient research on these outcomes in sport clubs. The paper reports on the results of an online, primarily qualitative questionnaire study conducted with members of collegiate student Equestrian sport clubs. Data come from $50 \mathrm{club}$ members participating in such organizations at 15 institutions in the U.S. The respondents completed a survey in which they were asked about their motivation for joining the organization and what they believed they learned as a result of their participation. The respondents reported equestrian and interpersonal reasons for joining, and that participation increased their development in a number of academic and professional areas, especially in terms of work ethic or time management or balance, collaboration or communication or teamwork, and leadership.
\end{abstract}

Keywords: Student organizations, out-of-class learning, engagement, authentic learning, student development, equestrian

\section{Introduction and Literature Review}

Theoretical ideas and empirical research about the importance of involvement in university life for learning, development, and persistence have been in the literature for many years (Astin, 1984; Foubert \& Grainger, 2006; Hernandez, Hogan, Hathaway, \& Lovell, 1999; Kuh, 1995; Terenzini, Pascarella, \& Blimling, 1996). The general idea is that greater involvement in out-ofclass experiences, broadly defined, can contribute to various positive learning and developmental outcomes. Proposed intervening variables in this relationship include greater time on task, academic resources, exchange of ideas with others, social support, formation of important relationships, commitment to the institution, and changes in identity (Astin, 1996; Tinto, 1993; Winkle-Wagner, 2012). A number of studies (Astin, 1996; Baker, 2008; McCluskey-Titus, 2003; Thompson, Clark, Walker, \& Whyatt, 2013) have examined the role of student involvement in organizations or academic relationships on both learning and developmental outcomes. Not surprisingly, though researchers have reported positive results, involvement experiences are not equally effective in all settings or with all students in promoting positive change.

One type of involvement experience is active participation in collegiate student organizations and clubs, which often offer authentic and hands-on learning opportunities. Thus, there has been empirical research on the nature of outcomes from participation in various types

\footnotetext{
${ }^{1}$ Assistant Professor of Secondary Education, School of Teaching and Learning, Illinois State University, Campus Box 5330, Normal, IL 61790-5330, emikule@ilstu.edu.

${ }^{2}$ Cross Endowed Chair in the Scholarship of Teaching and Learning, and Professor of Sociology, Emeritus, Box 6370, Illinois State University, Normal Il 61790-6370, kmckinne@ilstu.edu.
} 
of student organizations. Learning and development outcomes have included changes in values, student engagement, or achievement. Much of this work, however, has been on students as members in one of only three types of organizations: student government (Kuh and Lund, 1994; Miles, 2011), fraternities and sororities (Kimbrough \& Hutcheson, 1998; Long, 2012; Pascarella, Flowers, \& Whitt, 2009; Patton, Bridges, \& Flowers, 2011; Pike, 2000), and formal intercollegiate athletics (Rishe, 2003). Results of this body of work have been mixed varying by outcome measure and student characteristic. Very generally, however, involvement in student government has a positive relationship with learning or development. Meanwhile, involvement in formal athletics has no, mixed, or negative relationships, and involvement in fraternities and sororities has positive, mixed, or negative relationships, especially in the case of fraternities.

Another type of student organization is a sport club. Some literature exists on the nature or outcomes of participation at the collegiate level in campus recreation programs or in specific sport clubs (Bradley, Phillipi, \& Bryant, 1992; Bryant, Banta, \& Bradley, 1995; Haines, 2001; Hall, Forrester, \& Borsz, 2008; Hall-Yannessa \& Forrester, 2004; Huesman, Brown, Lee, Kellogg, \& Radcliffe, 2009). These studies have very different purposes, samples, variables, and methods. For example, Haines (2001), using questionnaires with undergraduates, reports that the respondents believed that their involvement in university recreation contributed to many positive outcomes, particularly in terms of fitness, feeling of physical well-being, physical strength, sense of accomplishment, and stress reduction. In a study on leadership development in sport club officers using a multi-method approach, Hall-Yannessa and Forrester (2004) found that the top five self-reported, post-test leadership skills were respecting the rights of others, being sensitive to those different from them, understanding consequences of one's actions, relating well to the opposite gender in a work-type context, and identifying their personal values. Hall, Forrester, and Borsz (2008), in a study of student leaders in sport clubs, identified seven skills that the respondents reported strengthened including, organizing, planning and delegating, balancing academic, personal, and professional roles, motivating/influencing others and being a mentor/role model, problem solving and decision making, communication skills, working with others, and giving and receiving feedback. Finally, McKinny \& Mikulec (2012) found that members of a campus sport club viewed their participation as beneficial in terms of providing opportunities to interact with new people, developing relationships with others who shared a common interest, and adding skills to include on their resumes.

The purpose of the present study is to report the reasons for involvement in, and the perceived learning outcomes from participation in, one type of collegiate sport club: equestrian clubs and teams. This study helps to fill gaps in the literature on out-of-class learning and involvement in terms of type of student organization studied, data from students at multiple institutions, and the need for more qualitative data, as well as in the scholarship of teaching and learning (SoTL) literature which focuses on learning outcomes gained from classes or academic programs but much less often on out-of-class co- or extra-curricular experiences. The study seeks to answer the following guiding questions:

1. Why do members choose to participate in a collegiate equestrian sport club?

2. How do members perceive their participation in a collegiate equestrian sport club has influenced their learning beyond equestrian skills? 


\section{Methodology}

\section{Procedure and Respondents}

The purposive sample for this study consisted of respondents from the researchers' home institution, universities within the Intercollegiate Horse Show Association (IHSA) region where the home institution competes, and universities and colleges nationwide that offer student equestrian sport clubs and organizations. Lists of the institutions in home institution's region and nation-wide, as well as contact information are publically available (Campus Equestrian, 2012).

Using these lists, the researchers emailed club presidents and advisers and asked that they forward the online survey link to the current members of the clubs and teams, as well as alumni. The email contained an invitation to participate in the study, information about the study and the URL to access the on-line questionnaire. The researchers had obtained Institutional Review Board approval for the study prior to contacting potential participants. When respondents accessed the questionnaire, they were presented with the informed consent statement. They were to select "yes" or "no" that they had read, understood and consented to the statement before proceeding to the questionnaire. All participation was voluntary and anonymous. The researchers sent the survey request at the midpoint of the spring semester and allowed 30 days response time.

A total of 50 respondents completed the survey, 14 from the home institution, 12 from four universities within the home institution's IHSA region, and 24 from ten colleges and universities nationwide. Since it is possible to occupy up to three roles within an organization, club member, team member and executive board members, the respondents identified all of the roles they occupied. See Table 1 for participant demographics.

\section{Measures}

The researchers created a self-administered, on-line questionnaire consisting of both closed and open-ended questions. The researchers collected participant demographic and background information including year in school, the roles they have had, such as club member, team member, and/or executive board member, and the number of semesters they have been members of the campus equestrian organization. For the purposes of this study, executive board is defined as those organization members who held elected positions such as president, vice president, secretary, treasurer, and show coordinator.

The respondents answered five open-ended questions that were designed to elicit information about motivation for participating in a colleague equestrian organization. See Appendix 1 for the open-ended questions. Finally, the respondents rated the extent to which they believed their participation in the Equestrian club and/or team had increased their development of several skills or knowledge areas $(1=$ not at all; $7=$ very much $)$. The list of skills or knowledge areas came from both the learning outcomes discussed in related prior literature and from our own anecdotal observations of the students in our campus equestrian club. These skills or knowledge areas included the following: leadership, team work, conflict management, organization, event planning, tolerance for diversity, work ethic, oral communication, written communication, and critical thinking. 


\section{Table 1}

Participant Demographics

\begin{tabular}{|l|l|l|l|}
\hline & $\begin{array}{l}\text { Home Institution } \\
\mathrm{n}=14\end{array}$ & $\begin{array}{l}\text { Regional } \\
\mathrm{n}=12\end{array}$ & $\begin{array}{l}\text { National } \\
\mathrm{n}=24\end{array}$ \\
\hline Year in School & \multicolumn{3}{|l|}{} \\
\hline Alumnus & $0(0.0)$ & $3(.25)$ & $6(.25)$ \\
\hline Senior & $3(.21)$ & $2(.17)$ & $4(.17)$ \\
\hline Junior & $8(.58)$ & $3(.25)$ & $4(.17)$ \\
\hline Sophomore & $2(.14)$ & $0(0.0)$ & $7(.29)$ \\
\hline Freshman & $1(.07)$ & $4(.33)$ & $3(.12)$ \\
\hline Role & & $10(.83)$ & $14(.58)$ \\
\hline Club Member & $14(1.0)$ & $11(.92)$ & $14(.58)$ \\
\hline Team Member & $13(.93)$ & $6(.50)$ & $7(.29)$ \\
\hline Executive Board & $7(.50)$ & 4.0 & 4.9 \\
\hline $\begin{array}{l}\text { Average number of } \\
\text { semesters of } \\
\text { participation }\end{array}$ & 3.4 & & \\
\cline { 2 - 5 } & & &
\end{tabular}

\section{Data Analysis}

Given the exploratory nature of the study, and the purposive sample, the goal was to obtain qualitative and some quantitative descriptive data about respondents' reasons for participation in a collegiate equestrian team and perceived learning outcomes as a result. In order to interpret the participants' qualitative responses, the researchers followed the data coding procedures of constant comparative analysis (Glaser \& Strauss, 1967), which allows for a potentially deeper understanding of the experiences of the participants and impact of the project on them, as well as revealing their differences (Patton, 2002). Throughout the analysis, the researchers followed the three-level coding process: open coding, axial coding, and selective coding (Strauss \& Corbin, 1998).

For the open-ended questions, then, each researcher independently analyzed the responses and coded them for main ideas. The researchers then shared their individual coding results in order to resolve any differences, combine the codes, and determine common themes that emerged from the data. Thus, although there were five separate open-ended questions, there was a significant amount of overlap in the responses, which allowed the researchers to combine 
them. By asking more than one question and coding the responses across themes and between groups, the researchers were able to identify the most frequent responses about why students participated and the most common beliefs about perceived impact of participation both academically and professionally.

Quantitative descriptive data included the participants' ratings on the Likert-scale items about learning certain skills, the researchers took the mean rating per item in each group of respondents and compared them to one another in order to provide a quantitative descriptive analysis. Given the small N size of each group, the researchers did not perform statistical tests of significance for any differences.

\section{Results}

\section{Reasons for Participation}

The respondents reported a number of reasons for choosing to participate in their institution's Equestrian organization. See Appendix 2 for additional example quotes.

Meeting others with a shared interest in horses. One of the reported reasons was simply as a means of meeting others with a shared interest in horses while away at college. This shared interest served as a way to connect with other students whom they may not have met had they not participated in the organization.

At home I had a group of friends from my barn and wanted to find a group like that again down at school.

Opportunity to develop as a rider while at school. The respondents also saw participation as an opportunity to continue to ride and develop as a rider at college. For these respondents, it was important to maintain consistency in their riding and the university equestrian organization provided them with the resources and opportunity to continue to do so, especially for those who did not own a horse or could not bring their own horse to school with them. The phrase, 'catch riding' in the next quote refers to the fact that in IHSA competition, students do not ride their own horses or horses known to them, rather they ride horses provided by the home barn assigned to riders via a random drawing.

I chose to be involved because I could not bring my horse to college and it was a way to keep riding. Also, the catch riding of IHSA shows is fun. I love riding all different types of horses and have become a much better rider over the past two years.

Passion for and love of horses. Another common theme that emerged from the data was that participation in club and team activities was based on a passion for and love of horses. Although many of the respondents reported having previous experience with riding, or having their own horses, the equestrian organization provided them with an opportunity to engage in a related activity in which they were interested, but may not have been able to pursue previously.

I chose the team because I love horses and horseback riding and have always wanted to compete but never could before. I thought this would be a really good opportunity for me to learn about horses and gain a lot of riding skills and experience.

Opportunity to compete as team in an individual sport. A fourth theme was the idea of being part of a team while still competing in an individual sport. While competitive horseback riding is very much an individual sport, focusing on the horse and rider rather than the efforts 
and accomplishments of a group working together, many of the respondents viewed participation in their organization as a way of still having a team approach to the sport. For these respondents, the team provided a network of support in their continued development as riders, both in training and in competitions.

I am an avid equestrian and had participated on a team in high school. I played a lot of team sports growing up (soccer, baseball, softball, etc.) and was really looking for the support of a team in my riding career. The only thing I hoped to get as a member of this team was a group of friends that I could relate to and who would support me throughout my college career.

Preparation for a future career. Finally, there was a fifth theme at the national level that did not appear with the same frequency at the home institution and regional levels, which was that participation in the organization was good experience for a future career in the equine industry. Although this theme did not present in the Home or Regional groups, it did emerge as a theme that is distinct of the national group. This may be attributed to the fact that a number of the national level organizations are NCAA teams that compete at a different and more competitive level. For these respondents, the training, competing and networking with other equine professionals were not simply part of being a member of a student organization, but rather valuable resources to help them in their future career goals.

Our coach helps to teach us different training exercises and also different training techniques. This knowledge will be extremely helpful in our future as most of us plan on pursuing a career in the equine industry.

\section{Likert-item Ratings on Skill Development}

The second issue examined was the perceived impact of participation in an equestrian organization. The results from the Likert-scale items showed that, on average, respondents believed that participation in the Equestrians contributed to their development of the ten skills and knowledge areas. For development in each of the ten areas, the respondents from each subgroup gave ratings well above the mid-point of 4.0 on the scale $(1=$ not at all; $7=$ very much). Of the areas presented in this portion of the survey, Work Ethic, Oral Communication, and Leadership, with overall mean scores of 5.91, 5.70, and 5.66 within the home, regional and national levels respectively, were rated the highest in terms of development as a result of participation in the equestrian organization. At the national and local levels, Work Ethic ranked the highest of all skills, with mean scores of 6.38 and 5.93 respectively. Leadership skills were rated the highest by the regional group, with a mean score of 5.75. The skill development that was rated the lowest by all three groups was Written Communication, with mean scores of 4.64, 4.42, and 4.79 for the local, regional and national levels. See Figure 1.

\section{Perceived Impact of Participation}

Responses to the open-ended questions were also coded to assess perceived impact of participation in the organization on academics and professionalism. See Appendix 3 for additional example quotes.

Development of time management skills. While there were a number of common themes among the sub-groups, there were differences in ranking of importance, defined by the frequency of supporting comments provided in the open-ended responses. Among the various themes that 
emerged, one was how participation in an equestrian organization helped the respondents to develop as riders, but also provided a means for developing skills that would serve them after college. For instance, several respondents discussed how being part of the equestrian teams challenged them to manage their time more effectively between coursework on campus and lessons and shows off campus. Furthermore, for the respondents who owned or leased horses, there was the added component of horse care and management that they also had to factor into their busy schedules.

During my first semester on the Equestrian team, I balanced 21 credit hours, along with a part-time job 20-30 hours a week, while participating in all of the team activities and shows. That forced me to work my butt off to stay on top of all of my school work along with making enough money to pay my rent.

Collaboration and development of communication skills. Along with added responsibilities and time management, the respondents also reported that participation in the organization had a significant impact on their ability to work and communicate effectively with

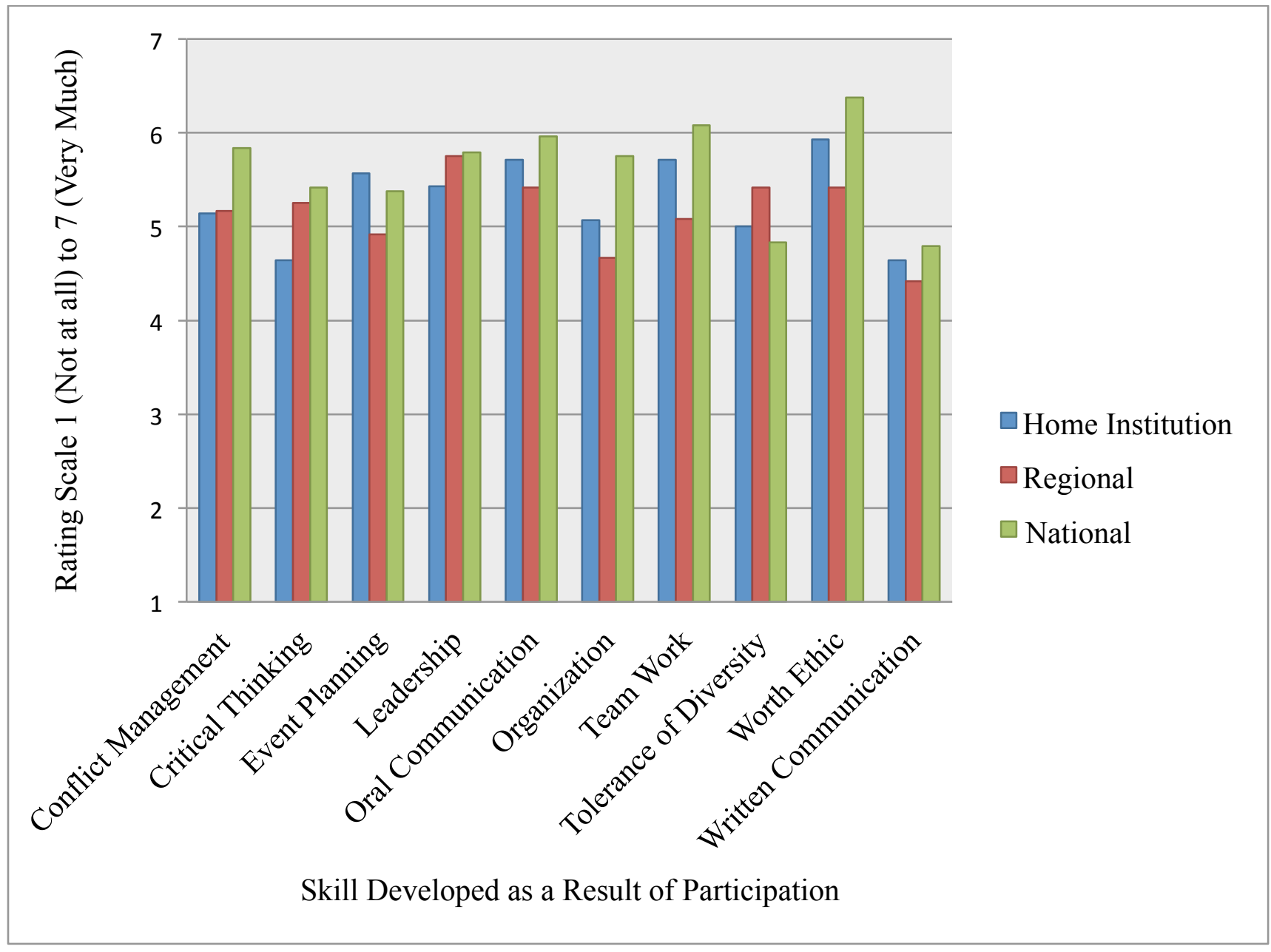

Figure 1. Mean Scores of Perceived Level of Skills Developed by Group

others. The respondents stated that they had to learn how to work with teammates, coaches, faculty and other equine professionals that did not always share their same point of view. They 
also discussed the importance of learning to communicate effectively with others and recognized this as an important aspect of their future careers, whether they were equine-related or not.

Being on the team helps to build up communication skills, leadership skills, and teamwork skills which you will need in your professional career. As an adult and professional, I have learned to be more patient with people as well as being sensitive about how I first bring on a new idea. Just like when you first ride a horse, one must ask softly and then increase the pressure.

Establishing a professional network. The respondents reported that participation in an equestrian organization not only helped to develop certain skills, but also provided resources and a network of other professionals. The respondents viewed this as a valuable component of their participation, and discussed how they hoped to establish professional networks of colleagues and trainers in order to have a strong foundation for their careers once they graduated from college.

I think being a member of the Equestrian team helps you create networks within the equine industry because you meet a lot of new people you may never have met otherwise. It also allows you to become friends with equestrians close to your age who may have similar thoughts and ideas about the equine industry.

Effectively balancing numerous responsibilities. Finally, the respondents described how their participation in an equestrian organization helped them to balance all of their responsibilities as well as to provide an outlet for stress. For many of the respondents, being on the team or in the club meant always having something to do that involved being with other members, and therefore was not only a support network in terms of riding, but also for academics and participation in various social activities.

Doing something athletic and fun is helping me stay sane and helping me cope with the stress of the academic environment. Also, the team is more laidback than other college sports, and this allows me to participate more easily and have time for work and study.

\section{Discussion}

\section{Overview of Findings}

The respondents reported several reasons for involvement in equestrian sport clubs and teams. Perhaps, not surprisingly, they indicated that they chose to participate for both interpersonal reasons and equestrian reasons. They wanted to meet people with similar interests and to be part of a group or team. They also wanted to continue riding and fuel their passion for horses. Respondents in the national group also mentioned participation would be good experience for a future equine career. This national group included some schools with formal academic equestrian programs, university owned or supported facilities and horses, and sometimes, National Collegiate Athletic Association (NCAA) teams in addition to sport clubs.

In terms of rating their development of ten skill/knowledge areas, Work Ethic ranked the highest of all skills for two sub-groups. Students responding to the questionnaire appeared to be quite active and, thus, engaged in the organization, often noting multiple roles and responsibilities, for instance, board member or officer, team and club member, and reporting an average of 3.4, 4.0, and 4.9 semesters of participation, for local, regional, and national groups, respectively. 
For the national subgroup, the high rating of work ethic development may also be the result of a number of respondents who participated in NCAA level Equestrian teams for which they would have to follow all NCAA rules and engage in a great deal of practice. Some of these schools also owned their own barns and horses that students helped maintain. Also, given the percentage of alumni responding in the national group, these results could be indicative of a greater level of development as the respondents had left the university and are currently involved in equine-related careers. Work Ethic was rated the highest by our local, home institution club/team members as well. This may be because the home institution's organization is an entirely volunteer club/team with no paid staff, no university facility, and little institutional support. All the work, even organizing and hosting an IHSA show, falls on the club/team members themselves. The lowest mean for skill development for all three subgroups was Written Communication which, while more frequent among the respondents who held positions on their respective executive boards, is not an activity in which a club or team member would participate on a regular basis as part of the organization.

In addition, the respondents' answers to open-ended questions indicate that respondents believe their membership in collegiate equestrian clubs resulted in a number of personal learning outcomes. There were consistencies between respondents' Likert-item ratings and some of the themes from the open-ended responses. Respondents across the groups noted that they developed as a rider or in horse care and management; improved time management and the ability to balance their many roles or obligations; learned more about leadership managing tasks and problem solving; and increased their abilities to communicate and work with others. The regional and national groups also discussed the benefits of participation for life after college, networking, and careers. Across all of the multiple measures, the three main themes of perceived learning/development to emerge were work ethic and time management, collaboration, communication and teamwork, and leadership.

Another important aspect of the equestrian organization is the variety of roles available to members. These roles can include membership in the club, on the competitive teams, on the executive board, or a combination of these. The data indicate that the roles available to students in an equestrian club/team allow for meaningful, authentic experiences as members must work successfully with professionals in off-campus settings. One aspect of a student equestrian organization that is somewhat unique compared to other student sport clubs is that team and executive board members must interact not only with faculty and other university representatives, but also with equine professionals not affiliated with the university, such as trainers, barn owners, and professional judges. This external interaction not only provides another means for organization members to develop skills such as communication and collaboration, but also requires that they learn how to negotiate between groups. For instance, ensuring university policies regarding student sport club respondents are understood and maintained by external groups, such as trainers and horse owners, over which students have no real control.

Furthermore, participation in a collegiate equestrian club/team provides an opportunity for members to compete individually with the support of a team, leading to increased knowledge of teamwork. Although competitive horseback riding is an individual sport, participation in a collegiate team allows for the members to compete while having the support of their teammates and coaches. Because equestrian sports are judged by external judges, members must also learn how to deal effectively with not only formal and public success and failure but also how to receive constructive criticism in their riding from teammates and coaches as well as experts 
beyond the local context. This adds yet another dimension of the supportive environment in which members can find themselves as they work to develop as riders and may help them take and use constructive criticism better in other areas of their lives such as in the classroom setting.

The findings presented here overlap somewhat with the limited research on sport clubs, helping to confirm these previous findings within a different sport club setting. Similar to past research, our respondents reported the following benefits or outcomes from their participation: sense of accomplishment, such as the development of riding skills in the present study, stress reduction (Haines, 2001), various leadership skills (Hall-Yannessa \& Forrester, 2004), time management or balancing various life roles, communication skills, working with others (Hall, Forrester, \& Borsz, 2008), and the opportunity to interact with and develop relationships with those with common interests (McKinny \& Mikulec, 2012). In addition, the respondents noted that their participation in the equestrians was characterized by or offered social support, the formation of important interpersonal relationships, the exchange of ideas with others, time management/time on task, and commitment to the institution, as seen in the level of involvement with the clubs and by competing for their schools.

Students' responses pointing to participation outcomes of social support, passion for activities, important relationships, help doing better with demands of school, for example, all seem likely to be part of engagement and institutional connection. These results, then, also support some of the intervening variables between involvement, or related constructs, and persistence as well as other positive academic and developmental outcomes proposed in various theories or models (Astin, 1984, 1996; Kuh, 1995; Terenzini, Pascarella, \& Blimling, 1996; Tinto, 1993).

\section{Implications}

The study has implications for faculty and academic staff members as well as student affairs professionals working with student organizations. For a number of the respondents in this study, active involvement in an equestrian organization was one step towards realizing career aspirations of working in the equine industry (Thompson, Clark, Walker, \& Whyatt, 2013). Therefore, it is possible that similar campus organizations, including extra-curricular ones, need more than a faculty advisor who simply signs forms and answers questions on by-laws and procedures. Rather, such organizations need faculty advisors that are invested in the group's activities, such as horse owners and competitors in our case, and helping to foster an understanding of both the direct and indirect outcomes of participation on the students involved including helping students to use their club involvement to learn about and network in any related career field. Advisers can facilitate student club members' engagement in activities similar to those in their career field, plan appropriate career events, find adults in the career field willing to serve as mentors, assist students in representation of club involvement on their resumes, and so on. Advisers can further assist, within the restrictions of club bylaws, match student members with officer roles and duties related to their majors or career plans, whether directly related to the club activity or not. For example, math or accounting majors might serve as treasurer, public relations or marketing majors as the membership and development officers, and so on. Likewise, faculty who are responsible for career courses, sessions or web pages for majors in their departments should think about strategies to explicitly and frequently connect careers in that major to students' participation and learning from co- and extra-curricular involvement not just from course work. 
In addition, student affairs professionals and faculty club advisers should work together, and with faculty across campus, to help students make more connections between extracurricular and co-curricular activities, and course work and learning outcomes. For example, this could be done by faculty simply taking a survey in class about activities and organizations in which students participate and their perceived learning, and then making an effort, when appropriate, to connect student involvement, for instance, values, skills, and, activities, to course material or assignments. Learning or teaching centers on campus could sponsor, as we have on our campus, 'student-faculty conversations on learning' where faculty and students come together for structured discussions about enhancing student learning. In this case, such a session would focus on the connections and integration of getting the most learning out of involvement in student organizations including extra-curricular ones. By doing these types of things, faculty and student affairs professionals can support student learning and development connected to participation in an organization whether or not they are directly involved as advisors.

\section{Limitations and Future Research}

There are two main limitations to the present study. First, the participants represented a purposive sample of current and alumni members of collegiate equestrian organizations that chose to participate. This, combined with a relatively small sample makes generalizability somewhat difficult. Although data-driven, this research can also be viewed as a case study. It should be noted, however, that 50 respondents representing 15 colleges and universities from around the United States participated in the study, and multiple measures were used to triangulate the results. Second, the study is an exploratory, descriptive study of student perceptions; there are no direct measures of learning, such as pre- and post-participation assessment of either equine, academic or professional skills. The survey did, however, allow participants to reflect on and share their perceived learning from club and team participation. Thus, the present study also honors student voices - a key theme in SoTL research.

In order to address these issues, further research is needed. For instance, it would be useful to repeat the study with other collegiate sport clubs in order to compare and contrast the reasons for, and learning outcomes of, participation. Also, future studies should include more questions about students' demographics, such as gender and age, in order to look at any relationships between such variables and learning outcomes. Furthermore, a larger, more diverse sample will be useful in terms of generalizability. Another facet of the data analysis could be an examination of learning outcomes by sub-groups, for example comparing and contrasting the experiences of club, team, and executive board members, as well as those respondents who held more than one role in the organization or spend more hours in club activities. Future studies should include additional indirect measures of outcomes such as interviews and focus groups as well as direct measures of learning and development such as the observation of behavioral indicators of learning at club events and team competitions, and pre-post-tests of certain skills. In addition, including questions or measures that more explicitly address or evoke data confirming any connections among the learning experiences and development from such out-ofclass learning with the learning in the classroom would be an important contribution to both the student affairs and scholarship of teaching and learning literatures.

In conclusion, this study makes a contribution to the field of the scholarship of teaching and learning by pushing the boundaries of appropriate subject matter and contexts for studies involving student learning and development. That is, it is critical for SoTL researchers to be 
reminded that learning at the collegiate level occurs both inside and outside of the traditional classroom setting. The present study also contributes to the student affairs and development literature by involving a multi-institutional sample, using descriptive data honoring student voices, and investigating an understudied type of organization, a sport club.

\section{Appendices}

\section{Appendix 1. Open-ended questions}

1. Why did you choose to participate in the Equestrians? What did you hope to get from being a member of this group?

2. How do you believe the different roles available (club/team/executive board) to you as a member of the Equestrians have or will impact you as an equestrian, student, and soon-to-beprofessional?

3. Describe some of your experiences, activities and interactions in the Club/Team/Executive Board. Discuss the types of values, skills, behaviors, personal and professional development, identity that you believe your participation in this organization has increased or affected. Discuss in terms of you as an equestrian, student, and soon-to-be professional.

4. Look back at your responses to the previous question. Discuss how or why or what particular experiences or interactions led to this learning and development. In other words, how did your experiences with the club/team contribute to your learning?

5. Were there any particular roles you occupied in the club/team that were especially important for what you learned or obtained from being in the club? If so, how? Why? 
Mikulec, E., \& McKinney, K.

\section{Appendix 2. Participant Quotes of Reasons for Choosing to Participate in an Equestrian Organization*}

\begin{tabular}{|c|c|c|}
\hline Home Institution $(n=14)$ & Regional $(n=12)$ & National $(n=24)$ \\
\hline $\begin{array}{l}\text { Meet people with a shared interest } \\
\text { At home I had a group of friends from } \\
\text { my barn and wanted to find a group } \\
\text { like that again down at school. }\end{array}$ & $\begin{array}{l}\text { Meet people with a shared interest } \\
\text { The team- I was a transfer student } \\
\text { looking for new friends with similar } \\
\text { interests. }\end{array}$ & $\begin{array}{l}\text { Continue to ride \& develop riding } \\
\text { skills at college } \\
\text { I thought this would be a really good } \\
\text { opportunity for me to learn about } \\
\text { horses and gain a lot of riding skills } \\
\text { and experience. }\end{array}$ \\
\hline $\begin{array}{l}\text { Continue to ride \& develop riding } \\
\text { skills at college } \\
\text { I grew as an equestrian and gained } \\
\text { valuable knowledge I wouldn't have in } \\
\text { a normal lesson setting. }\end{array}$ & $\begin{array}{l}\text { Continue to ride \& develop riding } \\
\text { skills at college } \\
\text { I wanted to learn new skills that } \\
\text { would benefit me in the saddle as } \\
\text { well as in any of life's situations. }\end{array}$ & $\begin{array}{l}\text { Passion for/Love of horses } \\
\text { I chose to participate because I am a } \\
\text { rider. I breathe and live horses. My } \\
\text { entire world revolves around horses. }\end{array}$ \\
\hline $\begin{array}{l}\text { Passion for/Love of horses } \\
\text { I've been riding since I was seven } \\
\text { years old. The Equestrian Team was } \\
\text { part of the reason I chose to attend } \\
\text { Home Institution. }\end{array}$ & $\begin{array}{l}\text { Passion for/Love of horses } \\
\text { Ever since I was little I've always } \\
\text { loved horses. }\end{array}$ & $\begin{array}{l}\text { Meet people with a shared interest } \\
\text { I was hoping to get some valuable } \\
\text { equestrian friends out of both the club } \\
\text { and team, which I did. }\end{array}$ \\
\hline \multirow[t]{2}{*}{$\begin{array}{l}\text { The team has grown a bond that we } \\
\text { have never experienced in the past. }\end{array}$} & \multirow[t]{2}{*}{$\begin{array}{l}\text { It's an individual sport, just you and } \\
\text { your horse. However, when I learned } \\
\text { about the team I thought it was an } \\
\text { interesting concept, being able to } \\
\text { compete in a sport which is usually } \\
\text { considered solo as a team. }\end{array}$} & $\begin{array}{l}\text { Be part of a team and compete at } \\
\text { shows } \\
\text { I played a lot of team sports growing } \\
\text { up and was really looking for the } \\
\text { support of a team in my riding career. }\end{array}$ \\
\hline & & $\begin{array}{l}\text { Good experience for future equine } \\
\text { career } \\
\text { Participation in the Equestrian Team } \\
\text { provided critical experience for a } \\
\text { developing equine professional. }\end{array}$ \\
\hline
\end{tabular}

*For each subgroup, themes are presented in order of frequency. Italicized material is direct quotes from students. 
Mikulec, E., \& McKinney, K.

Appendix 3. Participant Quotes for Perception of Impact of Participation in an Equestrian Organization*

\begin{tabular}{|c|c|c|}
\hline Home Institution $(n=14)$ & Regional $(\mathrm{n}=12)$ & National $(n=24)$ \\
\hline $\begin{array}{l}\text { Grow and develop as a rider } \\
\text { It has given me a ton of experience } \\
\text { riding horses I'm not familiar } \\
\text { with...this helps you as a rider and } \\
\text { to become more solid in your } \\
\text { abilities. }\end{array}$ & $\begin{array}{l}\text { Different skills to prepare for life } \\
\text { after college } \\
\text { They provide us with a taste of what } \\
\text { it might be like after college in } \\
\text { which we'll have career objectives } \\
\text { on both sides of the fence. }\end{array}$ & $\begin{array}{l}\text { Work well with different people, } \\
\text { develop social and communication } \\
\text { skills } \\
\text { I learned what it was like to be the } \\
\text { leader of a large group of people } \\
\text { with the same goals. }\end{array}$ \\
\hline $\begin{array}{l}\text { Time management } \\
\text { I learned to manage my time better } \\
\text { between the barn, work and school. }\end{array}$ & $\begin{array}{l}\text { Working with others collaboratively } \\
\text { It has impacted the way I work with } \\
\text { people. You must work together to } \\
\text { achieve success and its best to learn } \\
\text { from all levels. }\end{array}$ & $\begin{array}{l}\text { Develop skills for future career, } \\
\text { networking } \\
\text { It helps you create networks within } \\
\text { the equine industry because you meet } \\
\text { a lot of new people that you may not } \\
\text { have met otherwise. }\end{array}$ \\
\hline $\begin{array}{l}\text { Leadership / Problem-solving Skills } \\
\text { I have learned that sometimes } \\
\text { unpopular decisions need to be } \\
\text { made in order to appeal to the } \\
\text { greater good and club as a whole. }\end{array}$ & $\begin{array}{l}\text { Responsibility that comes with } \\
\text { managing different tasks } \\
\text { It has given me more experience } \\
\text { handling paperwork, negotiating } \\
\text { with outside contracts, and } \\
\text { communicating my ideas. }\end{array}$ & $\begin{array}{l}\text { Be a better student with more } \\
\text { personal responsibility and self- } \\
\text { discipline; balance } \\
\text { It is something athletic and fun to } \\
\text { help me stay sane and cope with the } \\
\text { stress of the academic environment. }\end{array}$ \\
\hline $\begin{array}{l}\text { Learning to work and communicate } \\
\text { with different people } \\
\text { As a student it has forced me to } \\
\text { work with adults and other students. }\end{array}$ & $\begin{array}{l}\text { Leadership / Problem-solving skills } \\
\text { I think many of the members } \\
\text { gravitated towards me and paid } \\
\text { attention to how I handled } \\
\text { situations. That caused me to try to } \\
\text { be more professional in my } \\
\text { language and actions. }\end{array}$ & $\begin{array}{l}\text { Horse care/management } \\
\text { I now see horses as an animal that } \\
\text { offers so much more than I thought, } \\
\text { whether it be an educational benefit, } \\
\text { spiritual or cultural. }\end{array}$ \\
\hline
\end{tabular}

*For each subgroup, themes are presented in order of frequency. Italicized material is direct quotes from students. 


\section{References}

Astin, A. W. (1996). Involvement in learning revisited: Lessons we have learned. Journal of College Student Development, 37(2), 123-134.

Astin, A. W. (1984). Student involvement: A developmental theory for higher education. Journal of College Student Personnel, July, 297-308.

Baker, C. N. (2008). Under-represented college students and extracurricular involvement: the effects of various student organizations on academic performance. Social Psychological Education, 11, 273-298. doi:10.1007/s11218-007-9050-y

Bradley, J. Phillipi, R., \& Bryant, J. (1992). Minorities benefit from their association with campus recreation programs. National Intramural-Recreational Sports Journal, Spring, 46-49.

Bryant, J. A., Banta, T. W., \& Bradley, J. L. (1995). Assessment provides insight into the impact and effectiveness of campus recreation programs. NASPA Journal, 32(2), 153-160.

Campus Equestrian. (2012). Retrieved from http://www.campusequestrian.com/

Foubert, J. D., \& Grainger, L. U. (2006). Effects of involvement in clubs and organizations on the psychosocial development of first-year and senior college students. NASPA Journal, 43(1), 166-182.

Glaser, B. G., \& Strauss, A. L. (1967). The discovery of grounded theory; strategies for qualitative research. Chicago, IL: Aldine Publishing Company.

Haines, D. J. (2001). Undergraduate student benefits from university recreation. NIRSA Journal, $25(1), 25-33$.

Hall, S. L., Forrester, S., \& Borsz, M. (2008). A constructivist case study examining the leadership development of undergraduate students in campus recreational sports. Journal of College Student Development, 49(2), 125-140. doi:10.1353/csd.2008.0010

Hall-Yannessa, S. L., \& Forrester, S. (2004). Differences in leadership development of club sport officers. Recreational Sports Journal, 28(1), 7-18.

Hernandez, K., Hogan, S., Hathaway, C., \& Lovell, C. D. (1999). Analysis of the literature on the impact of student involvement on student development and learning: More questions than answers? NASPA Journal, 36(3), 184-197.

Huesman, R. Jr., Brown, A. K., Giljae, L., Kellogg, J. P., \& Radcliffe, P. (2009). Gym bagsand mortar boards: Is use of campus recreation facilities related to student success? Journal of Student Affairs Research and Practice, 46(1), 50-71. doi:10.2202/1949-6605.5005 
Kimbrough, W. M., \& Hutcheson, P. A. (1998). The impact of membership in black Greek-letter organizations on black students' involvement in collegiate activities and their development of leadership skills. Journal of Negro Education, 67, 63-74. doi:10.2307/2668220

Kuh, G. D. (1995). The other curriculum: Out of class experiences associated with student learning and personal development. Journal of Higher Education, 66(2), 123-155. doi:10.2307/2943909

Kuh, G. D., \& Lund, J. P. (1994). What students gain from participating in student government. In M. C. Terrell and M. J. Cuyjet (Eds.), New directions for student services: No. 66. Developing student government leadership (pp. 5-17). San Francisco, CA: Jossey- Bass.

Long, L. D. (2012). Unchallenged, Professed Core Values: Do Undergraduate Fraternity/Sorority Members Actually Benefit in the Areas of Scholarship, Leadership, Service, and Friendship?, The College Student Affairs Journal, 31(2), 15-30.

McCluskey-Titus, P. (2003). Assessing what students learn from involvement in campus activities. Campus Activities Programming, March, 49-52.

McKinney, K. \& Mikulec, E. Perceived Learning Outcomes from Participation in a Registered Student Organization Sport Club. Paper presented at the annual meeting of the International Society for the Scholarship of Teaching and Learning, Hamilton, Canada, October 2012.

Miles, J. M. (2011). Reflections of student government association leaders: Implications for advisors. College Student Journal, 45(2), 324-332.

Pascarella, E. T., Flowers, L., \& Whitt, E. (2009) Cognitive effects of Greek affiliation in college: Additional evidence. Journal of Student Affairs Research and Practice, 46(3), 447-468. doi:10.2202/1949-6605.5020

Patton, L. D., Bridges, B. K., \& Flowers, L. A. (2011). Effects of Greek Affiliation on African American Students' Engagement: Difference by College Racial Composition. The College Student Affairs Journal, 30(2), 113-123.

Patton, M. Q. (2002). Qualitative research and evaluation methods. Thousand Oaks, CA: Sage.

Pike, G. R. (2000). The influence of fraternity or sorority membership on students' college experiences and cognitive development. Research in Higher Education, 41, 117-139. doi:10.1023/A:1007046513949

Rishe, P. J. (2003). A reexamination of how athletic success impacts graduation rates: Comparing student-athletes to all other undergraduates. The American Journal of Economics and Sociology, 62, 407-427. doi:10.1111/1536-7150.t01-2-00006

Strauss, A. L., \& Corbin, J. M. (1998). Basics of qualitative research : techniques and procedures for developing grounded theory. Thousand Oaks, CA: Sage Publications, Inc. 
Terenzini, P. T., Pascarella, E. T., \& Blimling, G. S. (1996). Students' out-of-class experiences and their influence on learning and cognitive development: A literature review. Journal of College Student Development, 37(2), 149-162.

Thompson, L. J., Clark, G., Walker, M., \& Whyatt, J. D. (2013). 'It's just like an extra string to your bow': Exploring higher education students' perceptions and experiences of extracurricular activity and employability. Active Learning in Higher Education, 14(2), 135-147.

doi:10.1177/1469787413481129

Tinto, V. (1993). Leaving college: Rethinking the causes and cures of student attrition (2nd ed.). Chicago, IL: University of Chicago Press.

Winkle-Wagner, R. (2012). Self, college experiences, and society: Rethinking the theoretical foundations of student development theory. College Student Affairs Journal, 30(2), 46-60. 